\title{
The present and future burden of urinary bladder cancer in the world
}

\author{
Martine Ploeg • Katja K. H. Aben • \\ Lambertus A. Kiemeney
}

Received: 13 January 2009 / Accepted: 26 January 2009 / Published online: 15 February 2009

(C) The Author(s) 2009. This article is published with open access at Springerlink.com

\begin{abstract}
Urinary bladder cancer (UBC) is a common disease worldwide. At any point in time 2.7 million people have a history of UBC. The incidence of UBC varies over the world with highest rates in developed communities. But the burden of UBC will increase in less developed areas of the world. These changes can be attributed to global changes in exposure to risk factors for UBC and growth and aging of the world population.
\end{abstract}

Keywords Urinary bladder cancer $\cdot$ Burden $\cdot$ Incidence $\cdot$ Worldwide $\cdot$ Changes

\section{Introduction}

More than 12 million new cases of cancer occur annually worldwide. Of those 5.4 million occur in developed countries and 6.7 million in developing countries $[1,2]$. Cancer

M. Ploeg · L. A. Kiemeney $(\varangle)$

Department of Urology,

Radboud University Nijmegen Medical Centre,

PO Box 9101, 6500 HB Nijmegen, The Netherlands

e-mail: s.vanwezel@ebh.umcn.nl

M. Ploeg

e-mail: m.ploeg@uro.umcn.nl

K. K. H. Aben - L. A. Kiemeney

Comprehensive Cancer Center East,

Nijmegen, The Netherlands

K. K. H. Aben · L. A. Kiemeney

Department of Epidemiology, Biostatistics and HTA,

Radboud University Nijmegen Medical Centre,

Nijmegen, The Netherlands occurrence in developing countries is predominated by tumor types that are related to viral and bacterial infections such as stomach, liver and cervical cancer. This may change in the next decades, however, because economical development goes along with a rising smoking prevalence and, consequently, with increasing trends of smokingrelated cancers such as urinary bladder cancer (UBC). In this short overview, we will describe the global occurrence, mortality and prevalence of UBC. In addition, we reflect on the growth and aging of the world population and its impact on the future bladder cancer burden.

\section{UBC occurrence is about three to four times higher in developed countries}

Urinary bladder cancer ranks ninth in worldwide cancer incidence. It is the seventh most common malignancy in men and seventeenth in women. Approximately 356,000 new bladder cancer cases $(274,000$ males and 83,000 females) occurred worldwide in 2002 [2, 3]. The worldwide age standardized incidence rate (ASR) is 10.1 per 100,000 for males and 2.5 per 100,000 for females. The incidence varies significantly between geographical regions or countries (Fig. 1), with highest rates $\left(\mathrm{ASR}_{0} \hat{=}=19.5\right.$ and $\mathrm{ASR}_{+}=$ $4.2)$ as well as absolute numbers $(n=225,242)$ observed in developed areas. Lower rates $\left(\mathrm{ASR}_{\hat{O}}=5.3\right.$ and $\mathrm{ASR}_{+}=$ 1.6) and absolute numbers $(n=130,971)$ are seen in less developed regions like Asia and almost all of Africa [2]. Part of this variability is artificial, however, and can be explained by differences in the definition and registration of UBC. Some cancer registries include non-invasive (pTis, pTa and PUNLMP) UBC in the incidence figures while others only report invasive ( $\geq \mathrm{pT} 1)$ cancers [4]. Also, differences exist in the registration of metachronous tumors in 


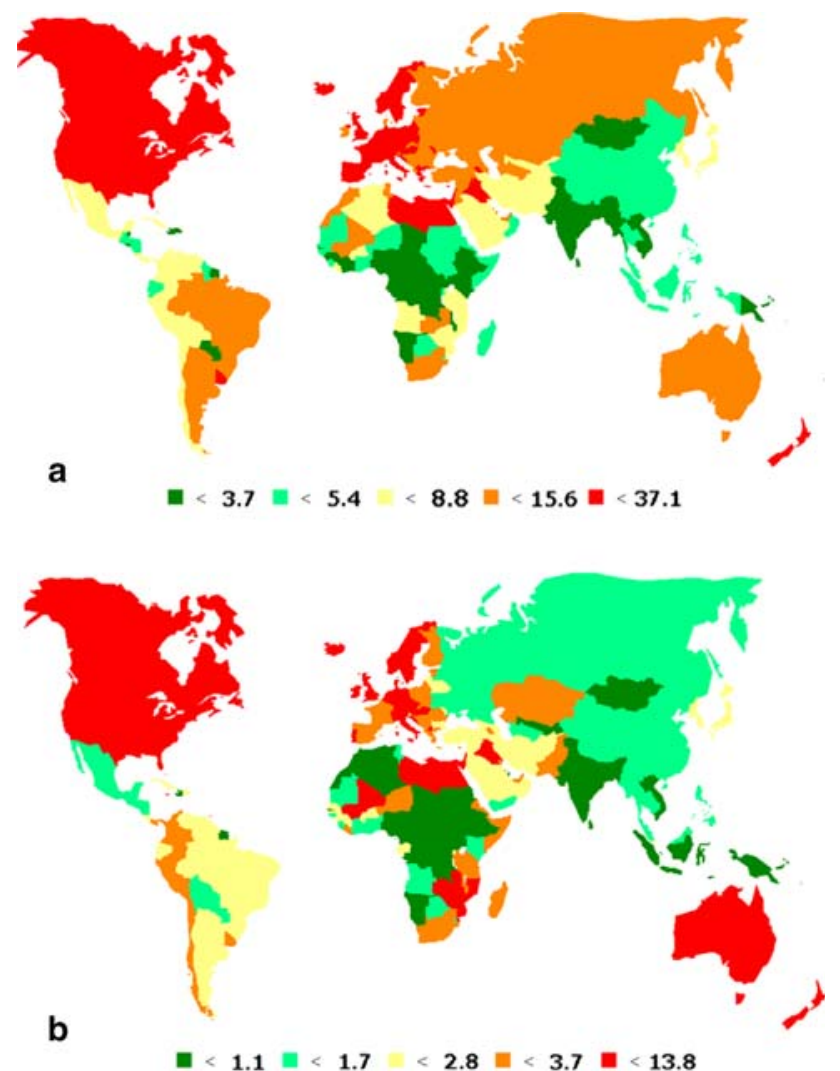

Fig. 1 Age standardized incidence rates per 100,000 for UBC in males (a) and females (b)

the bladder, especially in cases of muscle-invasive tumors following non-invasive UBC. Besides this artificial variability, worldwide differences in exposure to risk factors are largely responsible for the observed variability in occurrence. In Western countries, cigarette smoking, accounting for $50 \%$ of UBC in males and $35 \%$ in females [5], and occupational carcinogens are the most important risk factors for urothelial carcinoma (UC), which represents the majority of UBC in developed countries. Chronic urinary infection caused by Schistosoma haematobium (also known as schistosomiasis or bilharzia) is associated with the development of squamous cell carcinoma (SCC). In regions where this infection is endemic, like Egypt, SCC was for years the dominant histopathological type of UBC [6]. Because of the endemic infection, Egypt has the highest incidence of UBC in the world: the incidence of 37.1 per 100,000 males is almost two times higher than in Western communities [2].

\section{About 1 in 25 Western men and 1 in 80 women will be diagnosed with $\mathrm{UBC}$ sometime in life}

In both the USA and Western Europe, the lifetime probability for white males to develop UBC (pTa included) is more

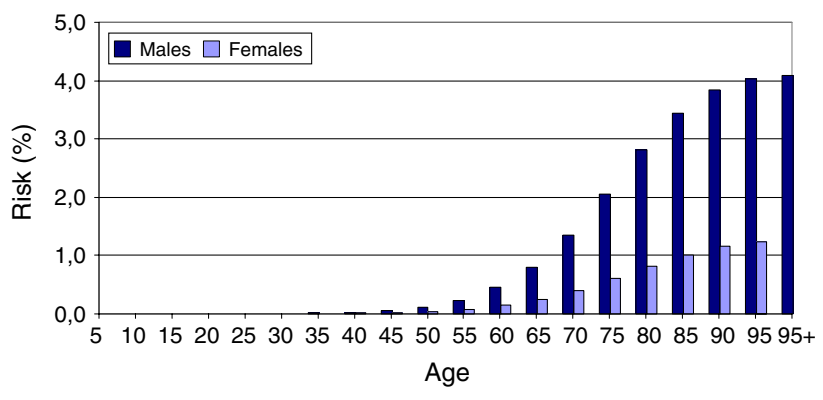

Fig. 2 Risk of developing UBC before a specific age for newborn white males and females

than $4 \%$ or 1 in 25 . In white females, this lifetime risk is about $1.2 \%$ or 1 in 80 [7,8]. Figure 2 shows the risk of developing UBC until a specific age for newborn males and females in the USA. Males have a risk of 0.45 and $2.81 \%$ to develop UBC before the age of 60 and 80 years, respectively. For females these risks are 0.14 and $0.82 \%$, respectively. In Figure 3 the risk of developing UBC within 10 years from a certain age is presented. It can be seen that both sexes have the highest risk to develop UBC within 10 years at the age of 75 . For males this risk is $2.32 \%$ and for females $0.560 \%$ [7]. In many developing countries, life expectancy is much lower than this 'high-occurrence age', which is one of the reasons why overall UBC incidence (not age-specific incidence) is lower in these countries.

\section{UBC mortality is less variable around the globe}

Worldwide approximately 145,000 patients die from UBC annually [2]. The global mortality rate among males is 4 per 100,000 versus 1.1 per 100,000 among females. The variability in UBC mortality around the world is not as large as that in UBC incidence (Fig. 4). The ASR (per 100,000) only varies between 5.6 in developed countries and 3.1 in developing countries for males. For females the ASR varies between 1.4 in developed countries and 0.9 in less developed areas. The

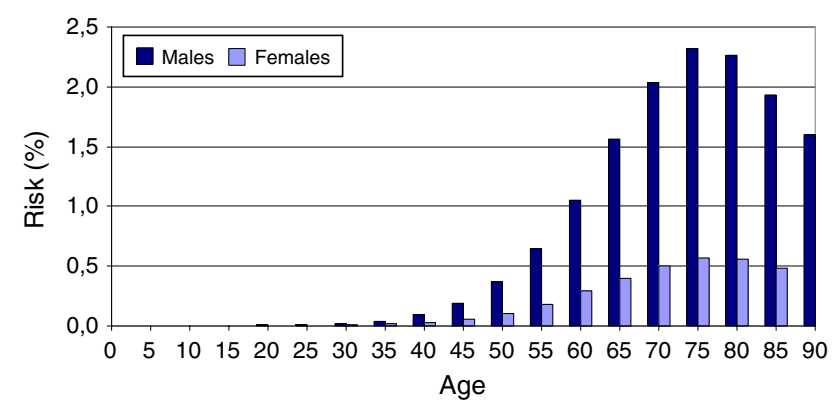

Fig. 3 Risk of developing UBC within 10 years from a specific age for white males and females 


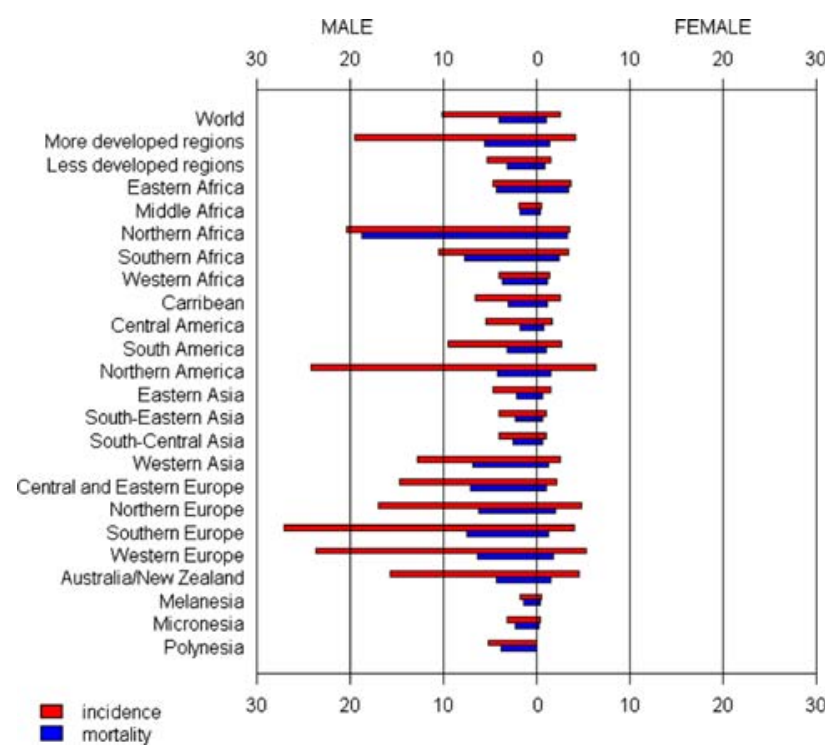

Fig. 4 Age standardized incidence and mortality rates for UBC per 100,000

smaller variability has to do with the fact that there are less definition and registration differences between countries with respect to $\geq \mathrm{pT} 2$ tumors which are responsible for most of the UBC mortality.

\section{Worldwide, at any point in time, 2.7 million people have a history of UBC}

The prevalence of UBC, or any other tumor, is difficult to assess. The number of patients alive with bladder cancer at a specific point in time is a function of incidence and 'duration of the disease': prevalence $=$ incidence $\times$ duration . Duration is, of course, related to survival but it is also related to the question of how long a patient with a history of UBC is considered to be a bladder cancer patient. For that reason, the so-called 'partial prevalence' refers to the number of patients still alive within a defined period following diagnosis (usually 5 or 10 years). The overall global 5 -year prevalence is estimated at 1,110,265 (860,299 males and 249,966 females) [2]. There are no good estimates of the number of UBC patients still alive at any point in time irrespective of the duration of time since their diagnosis. We may, however, obtain a crude estimate by extrapolating the USA figures. In the USA, each year approximately 69,000 patients are diagnosed and it is calculated that approximately 521,000 Americans are alive with bladder cancer [7]. According to the function mentioned above, the 'duration' of the disease is therefore 7.5 years. With 357,000 new cases worldwide each year, and ignoring global survival differences, the prevalence can be estimated at $357,000 \times 7.5=2,677,500$.

\section{The burden of UBC is decreasing in Western communities}

Bladder cancer incidence and mortality show a decrease in Western communities over the last decades. Karim-Kos et al. [9] found a decline in UBC occurrence in most countries of Europe (with the exception of Central Europe) since mid 1990. In the US declining trends in incidence were seen between 1987 and 2005 [7]. In Europe, mortality rates show a substantial decline over the last decade of $\sim 16 \%$ in men and $\sim 12 \%$ in women [10]. In the USA, UBC mortality rates show decreasing trends for men already since 1975 [11].

Changing habits of cigarette smoking is the most important explanation for the decline in incidence and mortality of UBC. The WHO reported a model of the tobacco epidemic (Fig. 5) which shows a decline in smoking prevalence in both men and women in most developed countries (stage 4) [12]. In USA adults, smoking rates declined from $52 \%$ in 1965 to $28 \%$ in 1990 for males and from 34 to $23 \%$ for females [13]. Western European men started smoking in the early twentieth century, while women started in the second half of the twentieth century. Smoking prevalence in Western Europe started to decline from the 1950s for men and from the mid 1970s for women [14].

Occupational chemicals most often linked to bladder cancer are aromatic amines. Nowadays, these hazardous carcinogens are banned from the workplace in most Western countries. With this, excess bladder cancer risk has largely be eliminated [15].

Another explanation for the decline in incidence and mortality rates of UBC is the change in bladder cancer staging systems over time. Until the WHO grading system was implemented in 1973, all low-grade non-invasive papillary tumors were called papillomas. After 1973, these tumors were defined as grade 1 papillocarcinomas (pTa) and resulted in an increase in the occurrence of UBC [16]. Again in 1998 a new classification system (WHO/ISUP) was published [17], which introduced the term "papillary urothelial neoplasm of low malignant potential" (PUNLMP). Lesions previously registered as pTaG1 in the commonly used 1973 WHO system were now called PUNLMP, a 'borderline' instead of malignant lesion.

\section{The burden of UBC will strongly increase in developing countries}

The geography of smoking is shifting from the developed to the developing world. Many low- and middle-income countries are still in the early stages of the tobacco epidemic (Fig. 5, stage 1 and 2) [18, 19]. The WHO reports an increase in tobacco use among males and females in large 
Fig. 5 Four stages of the tobacco epidemic

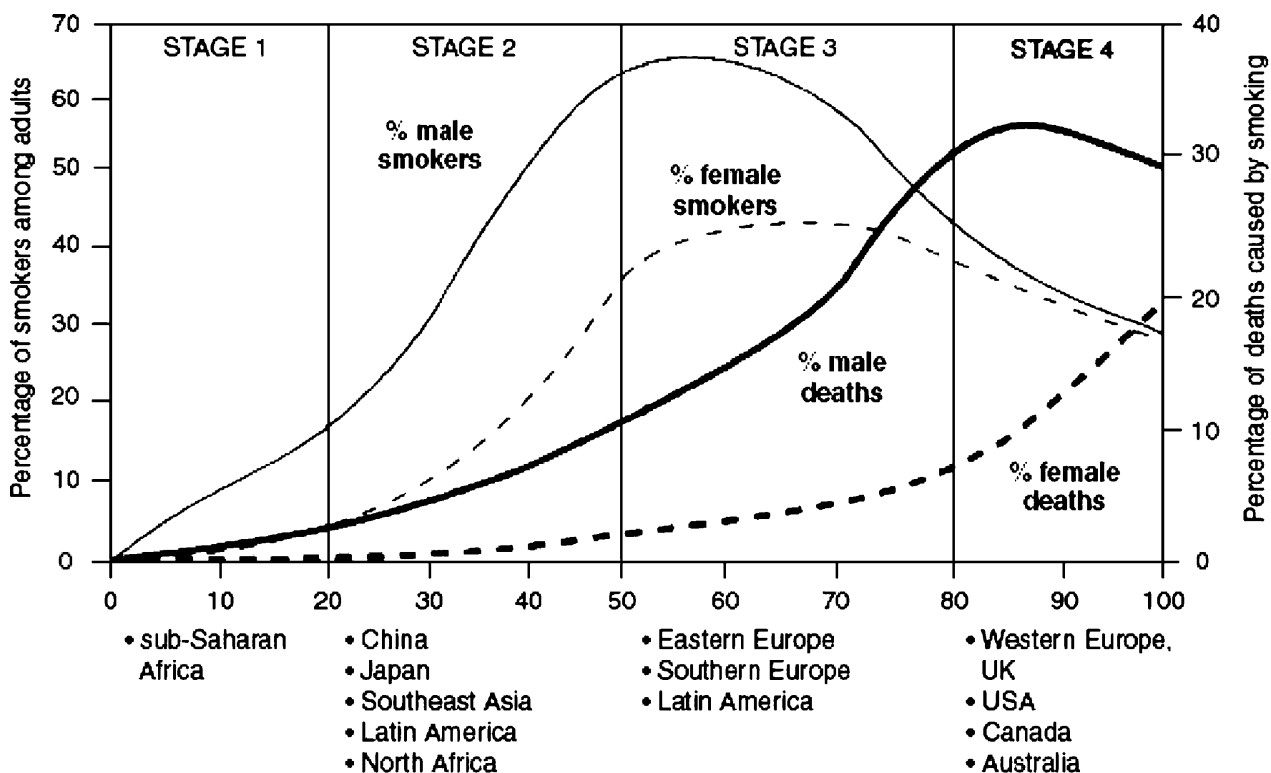

less developed areas of the world: Africa/Middle East, Eastern Europe/former Soviet Union and Asia/Australia showed an increase in tobacco use of 16.1, 8.7 and 6.5\%, respectively, in 2008 compared to 1998 [13, 20]. This will result in a serious increase in bladder cancer incidence in these communities in the next decades. Since tobacco advertising is banned by law in most Western countries, the tobacco industry is now focusing on the developing world. Even the Formula One racing, the sport most prominently associated with tobacco sponsorship, has moved its competition to Asia where regulation concerning tobacco is minimal [21, 22].

As mentioned before, SCC is the major histopathological subtype in areas where schistosomiasis is endemic. However, a shift towards UC is being observed as a result of a shift in risk factors. Following the construction of the Aswan High Dam (for irrigation and electricity) in the 1960s in Egypt, changes in the distribution of Schistosoma gradually took place because of the change in water flow. Infection with $S$. haematobium was replaced by S. mansoni [23], which causes intestinal disease instead of bladder disease. Furthermore, the introduction of effective oral antibilharzial drugs in Egypt since 1977 resulted in a significant decline in the prevalence of urinary schistosomiasis [24]. Together with changes in smoking behavior this has led to a decrease of SCC in Egypt from $78 \%$ in 1980 to $27 \%$ in 2005 [6]. With increasing urbanization and industrialization in many developing countries a similar shift from SCC toward UC is observed. More manufacturing processes are being transferred from developed to developing countries. In these countries occupational hygiene is less stringent, which may result in an increasing burden of occupational bladder cancer in those areas [15].
The effect of population aging on UBC occurrence will be strongest in developing countries

UBC is typically seen in the older patient: $>90 \%$ of cases occur in persons $\geq 55$ years of age. According to the United Nations, the world population is expected to increase by 2.5 billion over the next 40 years, passing to 9.2 billion in 2050 [25]. Half of this increase will be reflected in a rise in the population aged $>60$ years. In developed countries the population $>60$ years is expected to double while population size as a whole is expected to remain unchanged. Aging will be seen in all populations over the world. However, countries with a high birth rate will remain relatively young and increase rapidly. These countries experience the slowest population aging.

An increase in the total world population by 2.5 billion, absorbed mostly by the less developed regions, imply 2.5 billion additional people at risk for UBC. Together with population aging, progression of the tobacco epidemic and increasing exposure to occupational chemicals in developing communities, it is expected that a significant increase in incidence of UBC will occur in the foreseeable future. In developed countries where UBC occurrence will increase due to the advanced aging, this effect will be diminished or even neutralized by the decrease in exposure to risk factors like cigarette smoking and occupational chemicals.

\section{How to cope with the global burden of bladder cancer?}

The UBC burden is highest in developed communities but with increasing exposure to risk factors, a shift can be expected to the developing world in the near future. A major part of UBC (at least 50\% in Western countries) 
can be prevented with smoking cessation programs and protection from occupational chemical exposures [26]. Urgent action on cancer control should be taken with a focus on primary prevention of smoking in developing areas. The WHO Framework Convention on Tobacco Control (adopted May 2003) aims to suppress tobacco-related deaths and diseases. It campaigns, e.g., for a total ban on all forms of tobacco advertising, promotion and sponsorship by the tobacco industry, for price and tax measures and for education and public awareness (http://www.who.int/fctc/ en/). Another focus should be on a strict regulatory control on carcinogen exposure in the workplace in developing countries. All chemicals that are classified carcinogenic in the International Agency of Research for Cancer (IARC) Monographs (http://monographs.iarc.fr/) should be banned from the workplace or workers should at least be protected from the harmful effects.

Western communities need a different approach. Here, the call on public health care systems is strongly increasing because of the population aging, not because of an increasing exposure load. Research into the cost-effectiveness of different follow-up strategies in bladder cancer subgroups may be the best strategy to cope with this increasing health care demand.

\section{Conflict of interest statement None.}

Open Access This article is distributed under the terms of the Creative Commons Attribution Noncommercial License which permits any noncommercial use, distribution, and reproduction in any medium, provided the original author(s) and source are credited.

\section{References}

1. Garcia M, Jemal A, Ward EM, Center MM, Hao Y, Siegel RL, Thun MJ (2007) Global cancer facts and figs 2007. American Cancer Society, Atlanta

2. Ferlay J, Bray F, Pisani P, Parkin DM (2004) GLOBOCAN 2002: cancer incidence, mortality and prevalence worldwide. IARC CancerBase No. 5.version 2.0. IARC Press, Lyon

3. Parkin DM (2008) The global burden of urinary bladder cancer. Scand J Urol Nephrol Suppl 218:12-20. doi:10.1080/030088808 02285032

4. Crow P, Ritchie AW (2003) National and international variation in the registration of bladder cancer. BJU Int 92(6):563-566. doi:10.1046/j.1464-410X.2003.04421.x

5. Zeegers MP, Tan FE, Dorant E, van Den Brandt PA (2000) The impact of characteristics of cigarette smoking on urinary tract cancer risk: a meta-analysis of epidemiologic studies. Cancer 89(3):630-639. doi:10.1002/1097-0142(20000801)89:3<;630:: AID-CNCR19>;3.0.CO;2-Q

6. Felix AS, Soliman AS, Khaled H, Zaghloul MS, Banerjee M, ElBaradie $\mathrm{M}$ et al (2008) The changing patterns of bladder cancer in Egypt over the past 26 years. Cancer Causes Control 19(4):421429. doi:10.1007/s 10552-007-9104-7

7. Ries LAG, Melbert D, Krapcho M, Stinchcomb DG, Howlader N, Horner MJ et al (2008) SEER cancer statistics review, 1975-2005. National Cancer Institute, Bethesda. http://seer.cancer.gov/csr/
1975 2005/, based on November 2007 SEER data submission, posted to the SEER website

8. Kiemeney LA, Lemmers FA, Verhoeven RH, Aben KK, Honing C, de NJ et al (2008) The risk of cancer in the Netherlands. Ned Tijdschr Geneeskd 152(41):2233-2241

9. Karim-Kos HE, de Vries E, Soerjomataram I, Lemmens V, Siesling S, Coebergh JW (2008) Recent trends of cancer in Europe: a combined approach of incidence, survival and mortality for 17 cancer sites since the 1990s. Eur J Cancer 44(10):13451389. doi:10.1016/j.ejca.2007.12.015

10. Ferlay J, Randi G, Bosetti C, Levi F, Negri E, Boyle P et al (2008) Declining mortality from bladder cancer in Europe. BJU Int 101(1):11-19

11. Edwards BK, Brown ML, Wingo PA, Howe HL, Ward E, Ries LA et al (2005) Annual report to the nation on the status of cancer, 1975-2002, featuring population-based trends in cancer treatment. J Natl Cancer Inst 97(19):1407-1427

12. Lopez A, Collishaw N, Piha T (1994) A descriptive model of the cigarette epidemic in developed countries. Tob Control 3:242247. doi:10.1136/tc.3.3.242

13. Mackay J, Eriksen M (2002) The tobacco atlas. World Health Organization, Geneva

14. European Commission DHaCP2 Tobacco or health in the European Union: past, present and future. ASPECT Consortium

15. Delclos GL, Lerner SP (2008) Occupational risk factors. Scand J Urol Nephrol Suppl 218:58-63. doi:10.1080/03008880802284423

16. Kiemeney LA, Coebergh JW, Koper NP, van der Heijden LH, Pauwels RP, Schapers RF et al (1994) Bladder cancer incidence and survival in the south-eastern part of The Netherlands, 19751989. Eur J Cancer 30A(8):1134-1137. doi:10.1016/09598049(94)90472-3

17. Epstein JI, Amin MB, Reuter VR, Mostofi FK (1998) The World Health Organization/International Society of Urological Pathology consensus classification of urothelial (transitional cell) neoplasms of the urinary bladder. Bladder Consensus Conference Committee. Am J Surg Pathol 22(12):1435-1448. doi:10.1097/ 00000478-199812000-00001

18. Ezzati M, Lopez AD (2003) Estimates of global mortality attributable to smoking in 2000. Lancet 362(9387):847-852. doi:10.1016/ S0140-6736(03)14338-3

19. Ezzati M, Lopez AD (2003) Measuring the accumulated hazards of smoking: global and regional estimates for 2000. Tob Control 12(1):79-85. doi:10.1136/tc.12.1.79

20. Shafey O, Dolwick S, Guindon GE (2003) Tobacco control country profiles. The 12th World Conference on Tobacco or Health

21. Carlyle J, Collin J, Muggli ME, Hurt RD (2004) British American Tobacco and formula one motor racing. BMJ 329(7457):104-106. doi: $10.1136 / \mathrm{bmj} .329 .7457 .104$

22. Dewhirst T, Hunter A (2002) Tobacco sponsorship of formula one and CART auto racing: tobacco brand exposure and enhanced symbolic imagery through co-sponsors' third party advertising. Tob Control 11(2):146-150. doi:10.1136/tc.11.2.146

23. El-Khoby T, Galal N, Fenwick A, Barakat R, El-Hawey A, Nooman Z et al (2000) The epidemiology of schistosomiasis in Egypt: summary findings in nine governorates. Am J Trop Med Hyg 62:88-99

24. Gouda I, Mokhtar N, Bilal D, El-Bolkainy T, El-Bolkainy NM (2007) Bilharziasis and bladder cancer: a time trend analysis of 9843 patients. J Egypt Natl Cancer Inst 19(2):71-76

25. World Population Prospects (2007) The 2006 Revision. Exevutive Summary. United Nations, Department of Economic and Social Affairs

26. Wu X, Ros MM, Gu J, Kiemeney L (2008) Epidemiology and genetic susceptibility to bladder cancer. BJU Int 102:1207-1215. doi:10.1111/j.1464-410X.2008.07961.x 